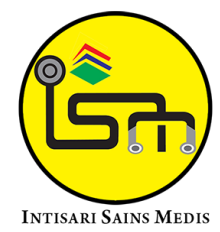

Published by Intisari Sains Medis

\title{
Kematian janin dalam kandungan pada ibu hamil dengan infeksi sifilis laten: laporan kasus
}

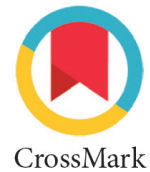

CrossMark

\author{
Hani Lusyana ${ }^{1 *}$, Lina Damayanti' ${ }^{1}$, Agus Walujo'
}

\section{ABSTRACT}

Background: Pregnant women and newborns are a group that is prone to contracting sexually transmitted infections, although they do not directly engage in high-risk sexual behavior. One that has an unexpected impact on pregnant women and newborns is syphilis by the bacterium Treponema pallidum. Transmission of syphilis from mother to fetus is usually worse when the infection in pregnant women is not detected or not appropriately treated early in pregnancy. This case report aims to evaluate fetal death in the womb in pregnant women with latent syphilis infection. Case Presentation: A 19-year-old pregnant woman aged 31-32 weeks diagnosed with late postpartum spontaneous Intrauterine Fetal Death (IUFD) with early latent syphilis. The diagnosis of syphilis was made based on the Veneral Disease Research Laboratory (VDRL) serological test (1:64), Treponema Pallidum Hemagglutination Assay (TPHA) (1:1,280), and without any mucocutaneous complaints. The patient received Benzathine Penicillin G 2.4 million IU single dose intramuscularly. The diagnosis of IUFD was made one day after the administration of therapy and the baby was born with multiple congenital abnormalities. Conclusion: Undiagnosed and adequately treated syphilis in pregnant women can result in perinatal death caused by multiple congenital abnormalities.

Keywords: Pregnant Women, Fetal Death, Congenital Abnormalities, Latent Syphilis.

Cite This Article: Lusyana, H., Damayanti, L., Walujo, A. 2021.Kematian janin dalam kandungan pada ibu hamil dengan infeksi sifilis laten: laporan kasus. Intisari Sains Medis 12(2): 582-585. D0I: 10.15562/ism.v12i2.1009

\section{ABSTRAK}

Latar Belakang: Ibu hamil dan bayi baru lahir merupakan kelompok rawan tertular infeksi menular seksual, walaupun tidak secara langsung berperilaku seksual resiko tinggi. Salah satu yang memiliki dampak kelahiran yang tidak diharapkan pada ibu hamil dan bayi baru lahir adalah Siflis oleh bakteri Treponema pallidum. Transmisi siflis dari ibu ke janin biasanya berakibat buruk ketika infeksi pada ibu hamil tidak terdeteksi atau tidak diobati secara benar di awal kehamilan. Laporan kasus ini bertujuan mengevaluasi kematian janin dalam kandungan pada ibu hamil dengan infeksi sifilis laten.

Presentasi Kasus: Seorang wanita hamil berusia 19 tahun usia kehamilan 31-32 minggu dengan diagnosis akhir postpartum spontan Intrauterine Fetal Death (IUFD) dengan siflis laten dini. Diagnosis siflis ditegakkan berdasarkan tes serologis Veneral Disease Research Laboratory (VDRL) (1:64), Treponema Pallidum Hemagglutination Assay (TPHA) (1:1.280), dan tanpa adanya keluhan mukokutaneus. Pasien mendapatkan terapi Benzatin Penisilin G 2.4 juta IU single dose secara intramuskular. Diagnosis IUFD ditegakkan satu hari setelah pemberian terapi dan bayi yang dilahirkan memiliki kelainan kongenital multipel.

Kesimpulan: Sifilis pada ibu hamil yang tidak terdiagnosis dan diterapi dengan adekuat dapat mengakibatkan terjadinya kematian perinatal yang disebabkan oleh kelainan kongenital multipel.

Kata kunci: Ibu Hamil, Kematian Janin, Kelainan Kongenital, Sifilis Laten.

Sitasi Artikel ini: Lusyana, H., Damayanti, L., Walujo, A. 2021.Kematian janin dalam kandungan pada ibu hamil dengan infeksi sifilis laten: laporan kasus. Intisari Sains Medis 12(2): 582-585. D0I: 10.15562/ism.v12i2.1009 


\section{PENDAHULUAN}

Sifilis merupakan penyakit infeksi menular seksual yang disebabkan oleh bakteri Treponema pallidum. ${ }^{1}$ Sifilis dibagi menjadi 4 fase berdasarkan gejala klinisnya yaitu sifilis fase primer, sekunder, laten, dan tersier. ${ }^{2}$ Tidak ditemukannya gejala klinis pada pemeriksaan namun didapatkan hasil tes serologis positif merupakan tanda dari sifilis laten. ${ }^{3}$ Penularan yang paling sering melalui hubungan seksual, dan yang terpenting transmisi infeksi dari ibu hamil ke anak dalam kandungan dapat terjadi. ${ }^{4}$ Transmisi sifilis dari ibu ke anak biasanya berakibat buruk pada janin ketika infeksi pada ibu hamil tidak terdeteksi atau tidak diobati secara benar di awal kehamilan. Kehamilan dengan infeksi sifilis laten berakibat fatal pada lebih dari setengah kasus. ${ }^{1}$

Tingkat morbiditas dan mortalitas karena sifilis kongenital termasuk tinggi. Menurut data World Health Organization (WHO) tahun 2012 di seluruh dunia terdapat 350.000 kasus kehamilan buruk yang diakibatkan oleh sifilis, diantaranya 143.000 kasus kematian dini pada janin/ lahir mati dan 62.000 kasus kematian neonatus. ${ }^{5}$ WHO juga memperkirakan setiap tahun terdapat 1,5 juta ibu hamil yang terinfeksi sifilis, dimana 520.000 kasus diantaranya terkena komplikasi berupa kematian janin pada kandungan, berat badan janin rendah, dan infeksi sifilis kongenital pada bayi. ${ }^{4}$

Berdasarkan pemaparan di atas, maka laporan kasus ini mencoba mengevaluasi kematian janin dalam kandungan pada ibu hamil terinfeksi sifilis laten dini yang tidak mendapatkan terapi secara adekuat.

\section{LAPORAN KASUS}

Seorang wanita hamil berusia 19 tahun, usia kehamilan 29-30 minggu, dirujuk dari Puskesmas setempat ke Poliklinik kami dengan membawa hasil laboratorium sifilis positif. Pasien baru melakukan pemeriksaan darah untuk skrining kehamilan. Dari anamnesis didapatkan pasien tidak mengeluhkan adanya gejala subjektif atau objektif pada alat kelamin ataupun di kulit selama dan sebelum kehamilan. Pasien sudah menikah, hubungan seksual terakhir dengan suami 3 minggu yang lalu secara
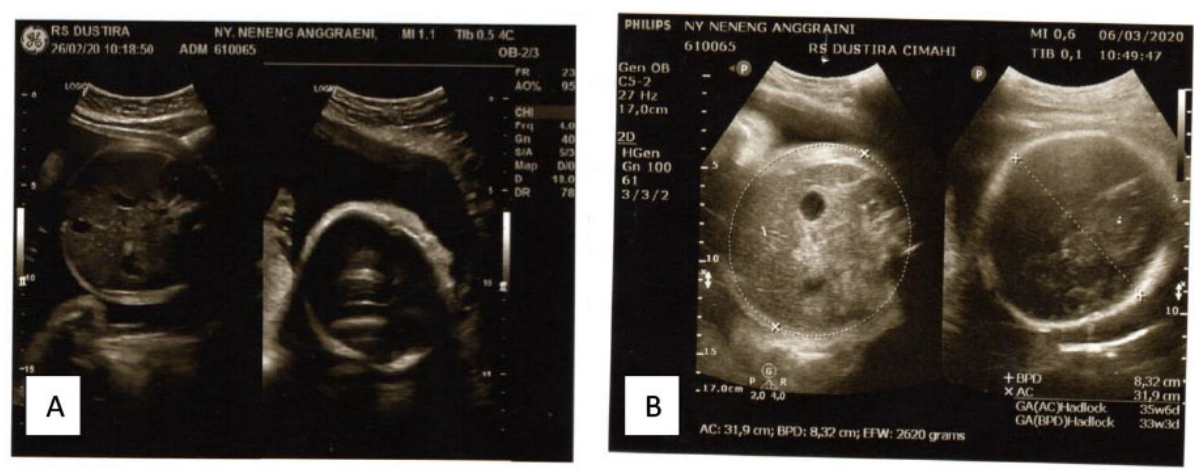

Gambar 1. Hasil pemeriksaan USG (A) kunjungan pertama dan (B) saat gerak bayi tidak dirasakan.

kelamin-kelamin, tanpa menggunakan kondom. Suami pasien terdiagnosis sifilis di puskesmas yang sama. Gejala subjektif maupun objektif pada suami disangkal. Keluhan suami mengarah ke Infeksi Menular Seksual (IMS) lain pun tidak didapatkan.

Ini merupakan kehamilan pertama pasien, pasien tidak memiliki riwayat abortus maupun lahir mati sebelumnya. Pasien diketahui memiliki riwayat Hari Pertama Haid terakhir (HPHT) pada 3 Agustus 2019. Gerakan bayi masih aktif dirasakan, belum didapatkan adanya tanda-tanda persalinan. Pasien melaksanakan Antenatal Care (ANC) secara rutin di bidan, tidak ditemukan adanya penyulit dan rutin minum asam folat. Pasien belum pernah melakukan Ultrasonografi (USG) kehamilan.

Pada pemeriksaan fisik didapatkan tanda vital dalam batas normal. Dari status generalis dan status dermatovenereologi tidak ditemukan kelainan. Hasil pemeriksaan serologis darah Veneral Disease Research Laboratory (VDRL) positif dengan titer 1:64 dan Treponema Pallidum Hemagglutination Assay (TPHA) positif dengan titer 1:1.280. Hasil USG oleh Dokter Spesialis Kandungan didapatkan hasil: kehamilan tunggal, hidup, intrauterin, belum masuk panggul, usia kehamilan 31-32 mg, 1795 gram, perempuan, Amniotic Fluid Index $(\mathrm{AFI})>20$, plasenta letak fundus dengan polihidramnion (Gambar 1A). Dokter spesialis kandungan menyetujui untuk pemberian injeksi Benzatin Penisilin 2,4 juta unit.

Pasien mendapatkan injeksi Benzatin Penisilin 2,4 juta unit intramuskular satu minggu kemudian. Satu hari setelah penyuntikan pasien kembali ke poliklinik kami dengan keluhan gerak bayi sudah tidak ada. Pasien merasa sejak sore hari penyuntikan dilakukan, gerakan dirasakan berkurang dan melemah. Malam harinya gerakan bayi tidak lagi dirasakan. Hasil anamnesis tidak didapatkan adanya gejala sistemik pada pasien. Pemeriksaan fisik pasien didapatkan tanda vital normal, status venereologi tidak ada kelainan. Pemeriksaan Detak Jantung Janin (DJJ) dengan USG doppler menunjukkan hasil negatif dan kematian bayi dalam kandungan dikonfirmasi dengan hasil USG (Gambar 1B).

Bayi dalam kandungan kemudian dilahirkan secara spontan. Bayi lahir dengan berat lahir 2.800 gram dan panjang badan $43 \mathrm{~cm}$. Hasil pengukuran didapatkan lingkar kepala $26 \mathrm{~cm}$, lingkar dada $27 \mathrm{~cm}$, dan lingkar perut $29 \mathrm{~cm}$. Pada pemeriksaan fisik bayi didapatkan derajat maserasi Grade 2. Tampak beberapa kelainan kongenital berupa low nasal bridge, webneck pada leher, molding ear aurikula sinistra. Pemeriksaaan fisik abdomen didapatkan perut cembung dengan fluid wave dan shifting dullness positif (Gambar 2).

\section{PEMBAHASAN}

Ibu hamil dan bayi baru lahir merupakan kelompok rawan tertular infeksi menular seksual (IMS), walaupun tidak secara langsung berperilaku seksual resiko tinggi. Sifilis pada ibu hamil dapat menyebabkan lahir mati dan abortus spontan (40\%), kematian perinatal (20\%), dan infeksi neonatal berat (20\%) atau bayi dengan 

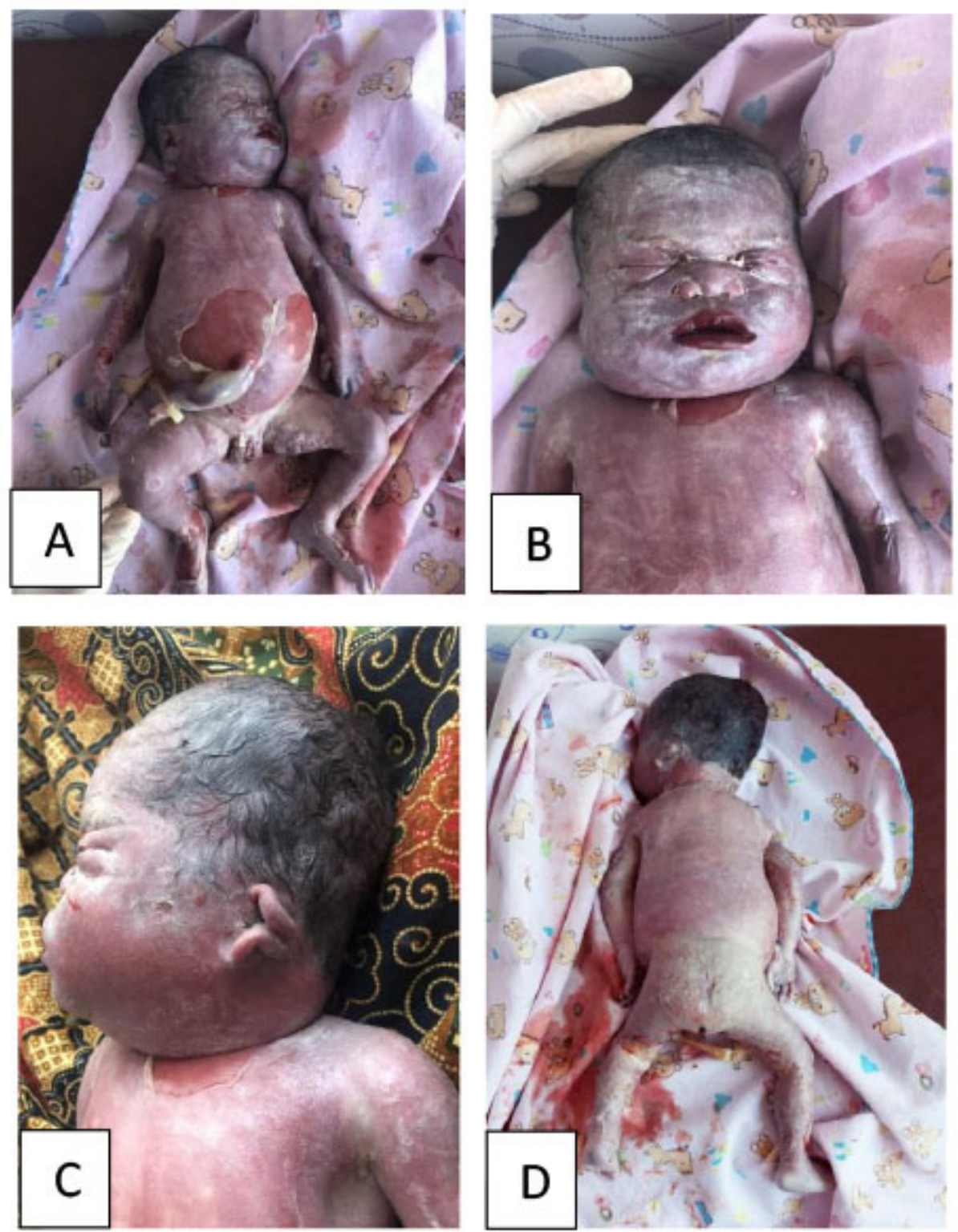

Gambar 2. Foto bayi setelah dilahirkan spontan dengan IUFD. (A) Maserasi Grade 2 dengan perut asites; (B) Hidung dengan low nasal bridge; (C) Molding ear pada aurikula sinistra; dan (D) Webneck pada leher.

berat badan lahir rendah (BBLR). ${ }^{6}$ Sumber lain menyebutkan kematian perinatal dialami pada $30 \%$ hingga $40 \%$ kasus sifilis kongenital. ${ }^{7}$ Pada kasus ini pasien seorang ibu hamil dengan sifilis laten dini yang mengalami kematian perinatal.

Pasien melakukan uji penapisan sifilis pada usia kehamilan trimester ketiga yang mana tidak sesuai dengan yang dianjurkan oleh Kementerian Kesehatan Republik Indonesia, WHO, maupun CDC. Kementrian Kesehatan Republik Indonesia (Kemenkes RI) melalui Pedoman Nasional Penanganan Infeksi Menular Seksual 2015, mencanangkan pemeriksaan sifilis ibu hamil pada kunjungan pertama (K1) yaitu sebelum usia kehamilan 12 minggu. ${ }^{8}$ WHO dan CDC pun menyarankan untuk melakukan skrining sifilis pada setiap ibu hamil saat pemeriksaan Antenatal Care (ANC) yang pertama. ${ }^{9}$

Manifestasi klinis sifilis laten ditandai dengan tidak adanya gejala namun didapatkan hasil pemeriksaan serologis reaktif. Sifilis laten terbagi lagi menjadi laten dini di mana sifilis didapatkan dalam 1 tahun terakhir dan laten lanjut bila sifilis didapatkan lebih dari 1 tahun. ${ }^{10}$ Klasifikasi berdasarkan titer di mana bila didapatkan titer RPR $£$ 1:4 dapat diinterpretasikan sebagai sifilis laten lanjut sedangkan titer $\mathrm{RPR}^{3} \quad$ 1:8 merupakan sifilis aktif dini. ${ }^{10}$ Pada pasien tidak didapatkan gejala mengarah ke sifilis primer atau sekunder sebelumnya. Dengan hasil titer VDRL 1:64 dan hasil pemeriksaan kurang dari 1 tahun, diagnosis dapat diklasifikasikan ke sifilis laten dini. Suami pasien juga terdiagnosis sifilis laten dan sudah mendapatkan terapi di puskesmas setempat.

Transmisi infeksi dari ibu ke bayi secara transplasenta dapat terjadi paling cepat di umur kehamilan 9-10 minggu. Kelainan pada janin dapat dideteksi dengan pemeriksaan Ultrasonografi (USG) setelah umur kehamilan 18-20 minggu, ketika janin menjadi imunokompeten dan terdapat respon inflamasi pada organ yang terinfeksi Treponema pallidum. ${ }^{11}$ Pemeriksaan USG dilakukan sebelum pasien diberikan terapi dan didapatkan adanya polihidramnion (pada hari pengamatan ke-8). Hal ini sesuai dengan studi oleh Rac MW et al. di mana polihidramnion menduduki peringkat ketiga terbanyak kelainan yang ditemukan pada USG setelah plasentomegali dan hepatomegali dari populasi ibu hamil terinfeksi sifilis. ${ }^{12}$

Ibu hamil yang memulai terapi pada trimester ketiga secara signifikan akan lebih tinggi kemungkinan mengalami kejadian tidak dikehendaki pada kehamilan dan/atau memiliki janin dengan infeksi sifilis yang berat. ${ }^{13}$ Tidak adanya gerakan pada bayi dirasakan oleh pasien keesokan hari setelah penyuntikan Benzatin Penisilin G dilakukan. Tidak adanya gerakan bayi dalam kandungan mengarahkan diagnosis ke arah Intra Uterine Fetal Death (IUFD), sesuai dengan studi oleh Jamal S dan Agarwal S pada tahun 2017. ${ }^{14}$ Usia pasien sesuai dengan studi sebelumnya yang menyatakan umur ibu 16-20 tahun merupakan umur yang tersering mengalami IUFD. ${ }^{14}$ Kematian bayi dikonfirmasi dengan pemeriksaan USG abdomen yang dan bayi kemudian dilahirkan secara spontan.

Bayi yang dilahirkan memiliki panjang badan dan berat badan sesuai dengan umur kehamilan dengan lingkar perut yang lebih besar dari lingkar kepala. Pada pemeriksaan fisik didapatkan adanya low nasal bridge atau saddle nose, webneck, molding ear, dan perut ascites. 
Bayi baru lahir dengan adanya gejala klinis sifilis kongenital menandakan adanya infeksi hebat. ${ }^{15}$ Kelainan antara lain adanya hidung tersumbat (snuffles) akibat mukus, darah, dan sekret yang bila berkembang secara progresif dan persisten akan mengakibatkan timbulnya ulkus hingga perforasi pada septum nasi atau terbentuknya saddle nose yang menjadi gejala khas sifilis. ${ }^{15,16}$ Gejala asites merupakan salah satu yang tersering ditemukan pada USG sifilis kongenital dan asites ditemukan pada pemeriksaan fisik setelah bayi dilahirkan. Adanya molding ear dan web neck menandakan kelainan kongenital tambahan yang mana mekanisme berkaitan dengan sifilis belum diketahui.

\section{SIMPULAN}

Sifilis pada ibu hamil yang tidak terdiagnosis dan diterapi dengan adekuat dapat mengakibatkan terjadinya kematian perinatal yang disebabkan oleh kelainan kongenital multipel. Skrining IMS di trimester pertama pada ibu hamil penting dilakukan untuk deteksi dini adanya infeksi sifilis.

\section{KONFLIK KEPENTINGAN}

Tidak terdapat konflik kepentingan dalam penulisan laporan kasus ini.

\section{ETIKA PENELITIAN}

Penelitian ini telah mendapatkan persetujuan tertulis (informed consent) oleh pasien dan telah mengikuti kaidah etika publikasi berdasarkan pedoman COPE maupun ICMJE.

\section{PENDANAAN}

Tidak ada.

\section{KONTRIBUSI PENULIS}

Seluruh penulis memiliki kontribusi yang sama dalam penulisan laporan kasus ini baik dari permohonan persetujuan pasien, pemilihan kasus, hingga evaluasi luaran klinis pasien melalui publikasi ilmiah.

\section{DAFTAR PUSTAKA}

1. Arando Lasagabaster M, Otero Guerra L. Syphilis. Sífilis. Enferm Infecc Microbiol Clin (Engl Ed). 2019;37(6):398-404.

2. Dupin N. Syphilis. Rev Med Interne. 2016;37(11):735-742.

3. Rac MW, Revell PA, Eppes CS. Syphilis during pregnancy: a preventable threat to maternal-fetal health. Am J Obstet Gynecol. 2017;216(4):352-363.

4. Plagens-Rotman K, Przybylska R, Gerke K, Piskorz-Szymendera M, Tomaszewska M, Sadowska-Przytocka A, et al. Syphilis and a pregnant woman: a real danger for the woman and the child. Postepy Dermatol Alergol. 2019;36(1):119-124.

5. Mattei PL, Beachkofsky TM, Gilson RT, Wisco OJ. Syphilis: a reemerging infection. Am Fam Physician. 2012;86(5):433-440.

6. Tsai S, Sun MY, Kuller JA, Rhee EHJ, DottersKatz S. Syphilis in Pregnancy. Obstet Gynecol Surv. 2019;74(9):557-564.

7. Su JR, Brooks LC, Davis DW, Torrone EA, Weinstock HS, Kamb ML. Congenital syphilis: trends in mortality and morbidity in the United States, 1999 through 2013. Am J Obstet Gynecol. 2016;214(3):381.e1-381.e3819.
8. Pedoman Nasional Tatalaksana Infeksi Menular Seksual. Jakarta: Direktorat Jenderal Pengendalian Penyakit dan Penyehatan Lingkungan. 2015.

9. Trivedi S, Taylor M, Kamb ML, Chou D. Evaluating coverage of maternal syphilis screening and treatment within antenatal care to guide service improvements for prevention of congenital syphilis in Countdown 2030 Countries. J Glob Health. 2020;10(1):010504.

10. Brown DL, Frank JE. Diagnosis and management of syphilis. Am Fam Physician. 2003;68(2):283-290.

11. Nathan L, Bohman VR, Sanchez PJ, Leos NK, Twickler DM, Wendel GD Jr. In utero infection with Treponema pallidum in early pregnancy. Prenat Diagn. 1997;17(2):119-123.

12. Rac MW, Bryant SN, McIntire DD, Cantey JB, Twickler DM, Wendel GD Jr, et al. Progression of ultrasound findings of fetal syphilis after maternal treatment. Am J Obstet Gynecol. 2014 Oct;211(4):426.e1-6.

13. Hawkes SJ, Gomez GB, Broutet N. Early antenatal care: does it make a difference to outcomes of pregnancy associated with syphilis? A systematic review and meta-analysis. PLoS One. 2013;8(2):e56713.

14. Jamal S, Agarwal S. IUFD incidence, causes and complications: a retrospective study done at a tertiary care centre in greater Noida, India. International Journal of Reproduction, Contraception, Obstetrics and Gynecology. 2017;6(12):5483-5487.

15. Krüger C, Malleyeck I. Congenital syphilis: still a serious, under-diagnosed threat for children in resource-poor countries. World J Pediatr. 2010;6(2):125-131.

16. Ostrander B, Bale JF. Congenital and perinatal infections. Handb Clin Neurol. 2019;162:133153.

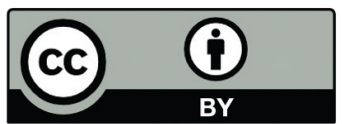

This work is licensed under a Creative Commons Attribution 